\title{
Біотехнологія пшениці. Вміст вільного проліну на початкових стадіях проростання зернівок генотипів пшениці озимої як маркер оцінки рівня жаростійкості
}

\section{Лариса Сергсєва, Лідія Хоменко, Лариса Броннікова}

Інститут фізіології рослин і генетики НАН України, Київ, Україна

Адреса для листування: Zlenko_lora@ukr.net

Отримано: 28.08.19; прийнято до друку: 20.10.19; опубліковано: 27.12.19

\begin{abstract}
Резюме. Метою сучасних біотехнологій пшениці, спрямованих на отримання стійких форм, $є$ оптимізація селекційного процесу. Оцінювали активність проростання та розвиток на початкових етапах онтогенезу різних за жаростійкістю (генотип $1<$ генотип $2<$ генотип 3 ) генотипів пшениці озимої, які піддавали прогріванню у воді, $\mathrm{t}^{0} 56^{0}$ впродовж 20 хвилин на стадії сухого насіння. Як маркер життедіяльності використано вміст вільного проліну. Рівень амінокислоти вимірювали на 1-у і 10-у добу після замочування. На 10-ту добу після температурної обробки зійшло 15,8; 27,0 і 57,0\% зернівок генотипів 1, 2, 3, відповідно. Лінійна довжина надземної частини проростків була: генотип $1-10-15$ см; генотип 2 - 12-18 см; генотип 3 - 18-20 см. Рівень вільного проліну, виміряний на 1-у добу після температурного стресу, суттєво переважав цей параметр у контрольних рослин. За вмістом проліну генотипи розподілялись: генотип $1<$ генотип $2<$ генотип 3 . На 10 -у добу вміст амінокислоти знижувався та зрівнювався із контрольними показниками. Ендогенний пролін утворювався внаслідок гідролізу білків зернівки. Зниження вмісту проліну, ймовірно, було наслідком його використання для формування та збільшення вегетативних органів молодих рослин. Рівень вільного проліну у проростках пшениці на ранніх етапах онтогенезу може бути маркером рівня жаростійкості генотипу. Такий підхід може сприяти пришвидшенню загального селекційного процесу добору жаростійких генотипів пшениці озимої.
\end{abstract}

Ключові слова: пшениця озима, прогрівання сухого насіння, проростання, пролін, $\mathrm{t}^{0}$-стійкість.

There is the wheat biotechnology. Free proline levels during early stages of fall wheat genotypes growth as the evaluation marker of heat tolerance

\section{Larisa Sergeeva, Lidia Khomenko, Larisa Bronnikova}

Institute of Plant Physiology and Genetics, National Academy of Scienses of Ukraine, Kyiv, Ukraine Correspondence: Zlenko_lora@ukr.net

\begin{abstract}
Modern biotechnologies of wheat are directed towards the acceleration of selection process. The obtaining of stress tolerant forms is especial object of this program. The reliable tolerance marker can provide a successful result. Free proline level is the established indicator of plant stress tolerance.

The post $t^{0}$-stress viability of three wheat genotypes there was evaluated. Genotypes differed for their heat tolerance (genotype $1<$ genotype $2<$ genotype 3 ). Dry grains were incubated in hot water $\left(\mathrm{t}^{0} 56^{0} \mathrm{C}\right.$ during 20 minutes) and then were germinated under normal conditions. Control variants were germinated on moist paper. Free proline levels were measured in young shoots on the 1-st and the 10-th days after $\mathrm{t}^{0}$-treament.

On the 10-th day after $\mathrm{t}^{0}$-treatment the variability among genotypes in shoots numbers appeared. 15,8 27,0 $\mathrm{i}$ $57,0 \%$ of $1,2,3$ genotypes were counted. The shoot lengths varied too: genotype $1-10-15 \mathrm{~cm}$; genotype $2-12-$ $18 \mathrm{~cm}$; genotype $3-18-20 \mathrm{~cm}$. At the first day after temperature treatment the free proline levels in tested shoots were higher than those parameters of control variants. The genotypes were disposed: genotype $1<$ genotype $2<$ genotype 3. At the 10-th day free proline contents decreased and corresponded to control data. There were no differences among genotypes. Endogenic proline was a result of grain proteins hydrolysis. The proline decrease was probably due to it using for young plant organs formation and growth. This event shows the degree of metabolism stress inhibition. The free proline levels in wheat shoots on early stages of plant germination may be the indicator of genotype heat tolerance Such approach can essentially accelerate wheat selection.
\end{abstract}

Key words: fall wheat, dry grain heat, germination, proline, $\mathrm{t}^{0}$-tolerance. 


\section{ВСТУП}

Прогресивні біологічні технології охоплюють зростаючу кількість сільськогосподарськоцінних культур. Це стосується і пшениці озимої (Triticum aestivum), оскільки при створенні нових високопродуктивних сортів, стійких до біотичних та абіотичних стресів, маніпуляції із культурою спрямовано на прискорення селекційного процесу $[1,2]$.

Сучасні зміни клімату стимулюють появу нових антропогенних чинників, які діють у поєднанні із несприятливими факторами довкілля та підсилюють стресове навантаження. Виникає проблема комбінованих стресів і потреба у рослинах, які будуть відзначатись високим адаптивним потенціалом.

У зв'язку 3 цим на перший план виступає завдання встановлення достовірного маркера/ маркерів контролю життєдіяльності організму, параметра, який міг би реагувати на зовнішній вплив. У такий спосіб може виявитися різниця/контраст у реакціях чутливих і стійких генотипів.

Молекулярні маркери, які є об'єктивною статичною характеристикою генотипу, не підпорядковані дії довкілля. До того ж вони досить вартісні та вимагають спеціальної підготовки від користувача або звертання до стороннього спеціаліста. 3 огляду на це постійно ведеться пошук системного індикатора, котрий координував би та взаємодіяв із усіма напрямками метаболізму. У низці перспективних iз цього погляду ендогенних речовин амінокислота $L$-пролін.

Особливості цієї сполуки базуються на іiі молекулярній структурі, а саме наявності $\alpha$ атому азоту у піролідиновому кільці. Унаслідок цього пролін (pro) не є субстратом для дії ферментів амінокислотного метаболізму декарбоксилаз, рацемаз, амінотрансфераз. Натомість метаболізм рго підпорядковується власній системі синтезу/деградації/транспорту. Рівень вільного pro $€$ суттєво динамічним показником, чутливим до зовнішніх факторів. Рослинні форми з різним ступенем природної стійкості навіть за нормальних умов здатні акумулювати різну кількість pro [3]. У той же час незаперечним фактом $є$ подія акумуляції цієї сполуки за дії різноманітних біотичних та абіотичних стресів. Тобто одночасно реалізується фізіологічна поліфункціональність дії вільного pro: детоксикуюча, осморегулювальна, стабілізуюча [4].

В останні роки цю сполуку почали розглядати як регуляторну молекулу, пов'язану
3 метаболізмом інших сумісних осмолітів, а саме вуглеводів. Так, установлено факт взаємної координації між сахарозою та проліндегідрогеназою (ПДГ, фермент деградації pro), а також геном ПДГ. In vivo в інтактних рослинах та in vitro у клітинних культурах відзначали одночасне або почергове зростання вмісту цих осмотично активних сполук [5]. Під час проведення експериментів параметри рівня вільного pro використовують як доведений показник стійкості до абіотичних стресорів [6]. Розвиваються нові напрями досліджень, пов'язані із створенням рослин - акумуляторів pro, котрі демонструють підвищений рівень стресстійкості [7].

У більшості біотехнологічних підходів pro вимірюють у рослинах із повністю сформованими вегетативними органами, піддаючи ï дії природних або модельованих стресів $[4,8-10]$. У такому випадку поза увагою лишається початок онтогенезу (початкові етапи проростання насінини), під час якого трофічним "постачальником" для проростка виступає ендосперм, склад якого генотипово зумовлений. За стресових умов рro може виступати як джерело вуглецю та азоту [4]. Тому пул вільного pro в такому разі може визначати рівень його витрачання на розвиток (активність проростання).

Отже, встановити рівень стійкості генотипів пшениці озимої на ранніх етапах онтогенезу актуально та важливо для селекції, оскільки в Україні почастішали періоди весняних або осінніх посух, які можуть супроводжуватись підвищеним температурним режимом. Дослідження можна вести в лабораторних умовах, дозовано створюючи температурний стрес, і вимірювати вміст вільного pro на будьякій стадії пророщування. При цьому додатково здійснюють порівняльний аналіз морфометричних показників також у динаміці. Такий алгоритм, на нашу думку, може встановити різницю між реакціями стресу та адаптації.

Метою нашого дослідження був аналіз рівня вільного проліну у пшениці озимої на ранніх етапах проростання зернівок без впливу та після дії стресового фактору.

\section{МАТЕРІАЛИ Й МЕТОДИ ДОСЛІДЖЕНЬ}

Об'єктом слугували проростки генотипів пшениці озимої, різні за ступенем жаростійкості, на початкових строках проростання. Генотипи (експериментальні лініiі) 3649; 3831; 8980 відповідно 1, 2, 3 у 
тексті та таблиці були отримані на ділянках Інституту фізіології рослин і генетики НАН України. Для досліду відібрано стандартизовані зернівки урожаю 2018 року. Замочування зернівок проводилось у лабораторних умовах 3 робочим температурним режимом.

Температурну обробку проводили за методикою [11], яка полягає у зануренні сухого насіння у воду $\left(\mathrm{t}^{\circ} 56^{\circ} \mathrm{C}\right)$ та витримуванні за стресових умов упродовж 20 хвилин. Подальше пророщування здійснювали на зволоженому фільтрувальному папері в термальній кімнаті за температури 22-25 . Схожість насіння визначали за методикою Держстандарту України (1994). Контролем слугували зернівки, замочені у проточній воді. Вміст вільного проліну визначали за методикою [12] на початкових етапах набухання зернівки (1-a доба після замочування) та на 10-ту добу експерименту. У першому випадку аналізували весь проросток, у другому використовували лише надземну частину. Для забезпечення необхідної біомаси тканини із 15-20 рослин подрібнювали, змішували і відбирали із суміші сукупну наважку. Життєздатність насіння визначали на 10-ту добу в \% схожості до всієї (300 шт.) кількості зерен. Дослід здійснювали у триразовій біологічній повторюваності. Статистичну обробку результатів проводили із залученням програмного забезпечення [13].

\section{РЕЗУЛЬТАТИ ТА ЇХ ОБГОВОРЕННЯ}

Аналізували післядію температурного стресу на проростання зернівок генотипів пшениці озимої. За кількістю пророслого насіння (10-а доба) досліджувані генотипи розподіляли так: 15,$8 ; 27,0$ і $57,0 \%$ для генотипів 1, 2, 3, відповідно. За той же період лінійна довжина надземної частини у генотипів 1, 2, 3 досягала: 10-15 см; 12-18 см; 18-20 см, відповідно.

Як маркер фізіологічного стану організму досліджували вміст вільного проліну у тканинах проростків різного строку розвитку (табл. 1).
Аналіз вмісту вільного проліну виявив ряд фактів. Рівень амінокислоти у молодих проростках суттєво залежав від умов зовнішнього впливу. На 1-у добу рівень pro у варіантів, які піддавали дії термального стресу, значно перевищував цей показник, виміряний у рослин за нормальних умов. Ця подія була властива всім генотипам. Під час проростання у насінні проходить процес масового гідролізу білків. Оскільки зернівки витримувались на воді за відсутності мінерального живлення, то джерелом сполуки за будь-яких умов виступали збагачені проліном білки (PRP, proline rich proteins) клітинної стінки [14]. Крім того, pro міг утворюватись і внаслідок гідролізу білків ендосперму. Гліадини, особливо $\omega$-гліадини, майже повністю складаються із повторюваних залишків глютаміну та проліну $[15,16]$.

Із збільшенням строку проростання рівень амінокислоти суттєво знижувався незалежно від умов досліду (нормальні умови, термальна обробка). Ця обставина може достовірно вказувати на іiі споживання рослинами. При цьому активність метаболізму pro у тканинах "стресових" проростків була вищою, на що вказує порівняння абсолютних показників 10-і доби. Ймовірно, підвищена температура додатково сприяла механічній деструкції оболонки зернівок усіх варіантів. В той же час результат дії протеолітичних ферментів у варіантів, які піддавали температурному впливу, був таким: генотип $1<$ генотип $2<$ генотип 3. Це виникло, ймовірно, внаслідок різного ступеня чутливості/стійкості генотипів до температурного стресу. Такий факт відзначався як на 1-у, так і на 10-у добу експерименту. Тобто можливо припустити, що це $є$ стабільною характеристикою життєдіяльності конкретного генотипу. Утворений pro виступав джерелом азоту та вуглецю. На це вказують формування та зростання вегетативних органів проростків. Варіабельність у лінійних розмірах виникла внаслідок різної інтенсивності проростання генотипів.

Таблиия 1

Вміст вільного проліну (мг\% / св. речовину) у молодих проростках пшениці озимої

\begin{tabular}{|c|c|c|c|c|}
\hline $\begin{array}{c}\text { Тривалість } \\
\text { пророщування }\end{array}$ & \multicolumn{2}{|c|}{1 -а доба } & \multicolumn{2}{c|}{$10-$ доба } \\
\hline $\begin{array}{c}\text { Умови } \\
\text { передобробки }\end{array}$ & Норм. умови & $\mathrm{t}^{0}$ обробка & Норм. умови & $\mathrm{t}^{0}$ обробка \\
\hline Генотип 1 & $32,52 \pm 3,11$ & $98,61 \pm 6,10$ & $2,15 \pm 0,10$ & $2,91 \pm 0,51$ \\
\hline Генотип 2 & $36,41 \pm 5,34$ & $115,84 \pm 6,39$ & $2,85 \pm 0,65$ & $3,48 \pm 0,47$ \\
\hline Генотип 3 & $20,60 \pm 2,99$ & $145,55 \pm 13,40$ & $3,53 \pm 1,13$ & $2,97 \pm 0,40$ \\
\hline
\end{tabular}


Біотехнологія пшениці. Вміст вільного проліну на початкових стадіях проростання зернівок генотипів пшеничі озимої як маркер очінки рівня жаростійкості

Культивування за нормальних умов, а також дія помірних стресів не завжди створює можливість встановити рівень стійкості окремого генотипу. Особливо це позначається при аналізі рослин із сформованими функціональними органами, які здатні підтримувати життєдіяльність цілісної рослини за рахунок транспорту та перерозподілу органічних компонентів. Фіксовані зміни $\epsilon$ наслідками різноманітних неспецифічних та індивідуальних (специфічних) фізіологічних реакцій. 3 іншого боку, аналіз змін, що мали місце у молодих проростків із обмеженим спрямуванням метаболізму, може виявляти загальні генетичні характеристики досліджуваного об'єкту.

Отримані результати вказують на те, що рівень вільного проліну, виміряний на початкових/ранніх етапах проростання зернівок пшениці, може бути показником не лише фізіологічного стану окремої рослини але й маркером жаростійкості генотипу.

\section{ВИСНОВКИ}

Отже, в ході проведених досліджень було встановлено: 1 - різні за ступенем жаростійкості генотипи пшениці озимої на початкових етапах органогенезу відзначались варіюванням проліну відповідно до встановленого рівня ознаки: 2 - вільний пролін у молодих проростків пшениці був продуктом дії гідролітичних ферментів; 3 - рівень вільного проліну під час проростання після температурного стресу може бути маркером жаростійкості генотипу.

\section{ЛIТЕРАТУРА}

1. Радченко, О.М. Поліморфізм генів господарсько-иінних ознак м'якої пшениці. Автореф. канд. біол. наук. Інститут фізіології рослин i генетики Національної академії наук України. 2019. Київ. 21 с.

2. Терлецкая, Н. В. Неспецифические реакции зерновых злаков на абиотические стрессы in vivo и in vitro. Алматы. 2012. 208 с.

3. Hasegawa, P. M.; Bressan, R. A.; Zhu, J. K.; Bohnert, H. J. Plant cellular and molecular responses to high salinity. Annu. Rev. Plant Physiol. Plant Mol. Biol. 2000, 51, pp 463-499.

4. Szabados, L.; Savoure, A. Proline: a multifunctional amino acid. Trends Plant Sci. 2010, 15. pp 89-97.
5. Mohammadkhani, N.; Heidari, R. Droughtinduced accumulation of soluble sugars and proline in two maize varieties. World App. Sci. J. 2008, 3(3), pp 448-453.

6. Kaur, G.; Asthir, B. Proline: a key player in plant abiotic stress tolerance. Biol. Plant. 2015, 59 (4), pp 609-619. Doi: https://doi.org/10/1007/s10535-0150549-3

7. Сергеева, Л. Е.; Михальская, С. И.; Комисаренко, А.Г. Современнье биотехнологии повышения устойчивости растений $\kappa$ осмотическим стрессам; Киев, 2019, 164 с.

8. Cha-Um, S.; Takabe, T.; Kirdmanee, C. Ion contents, relative electrolyte leakage, proline accumulation, photosynthetic abilities and growth characters of oil palm seedlings in response to salt stress. Pak. J. Bot. 2010, 42 (3), pp 2191-2120.

9. Kamran, M.; Shahbaz, M.; Ashraf, M.; Akram, N. A. Alleviation of drought-induced adverse effects in spring wheat (Triticum aestivum L.) using proline as a presowing seed treatment. Pak. J. Bot. 2009, 41, pp 621-632.

10. Kaur, D.; Grewal, S. K.; Kaur, J.; Singh, S. Differential proline metabolism in vegetative and reproductive tissues determine drought tolerance in chickpea. Biol. Plant. 2017, 61 (2), pp 359-366. Doi.org/10.1007/s10535-016-0695-2.

11. Диагностика устойчивости растений $\kappa$ стрессовым воздействиям. Под. ред. Г. В. Удовенко. ВИР: Ленинград, 1988, с 128-154.

12. Андрющенко, В. К.; Саянова, В. В.; Жученко, А. А.; Дьяченко, Н. И.; Чиликина, Л. А.; Дроздов, В. В.; Корочкина, С. К.; Череп, Г. И.; Медведев, В. В.; Нютин, Ю. И. Модификаџия метода определения пролина для выявления засухоустойчивых форм рода Lycopersicon Tourn. Изв. АН Молдавской ССР; 1981, № 4, с 55-60.

13. Доспехов, Б. А. Методика полевого опыта (с основами статистической обработки результатов исследований). 5-е изд. пополн., Агропромиздат: Москва, 1985, 351 с.

14. Stein, H.; Honig, A.; Miller, G.; Erster, O; Eilerberg, H.; Csonka, L. N. Elevation of free prolinerich protein levels by simultaneous manipulation of proline biosynthesis and degradation in plants. Plant Sci. 2011, 201, pp 140-150.

15. Žilić, S.; Barać, M.; Pešić, M.; Dodig, D.; Ignjatović-Micić, D. Characterization of proteins from grain of different bread and durum wheat genotypes. Int. J. Mol. Sci. 2011, 12. pp 5878-5894; doi: 10.3390/ijms 12095878

16. Chacraborty, K.; Khan, K. Biochemical and breadmaking properties of wheat protein components. Compositional differences revealed through quantitation and polyacrylamide gel electrophoresis of protein fractions from various isolation procedures. Cereal Chem. 1988, 65, pp 333-340. 